\title{
Application of blood cadmium analysis to industry using an atomic fluorescence method
}

\author{
G. S. FELL, J. M. OTTAWAY, AND F. E. R. HUSSEIN \\ From the Department of Pathological Biochemistry, Royal Infirmary, University of Glasgow, and \\ the Department of Pure and Applied Chemistry, Strathclyde University
}

ABSTRACT A flame photometric method using atomic fluorescence (AFS) for cadmium (Cd) estimation is described and applied to the measurement of $\mathrm{Cd}$ in blood. The AFS system employs a modified, low cost atomic absorption spectrophotometer, with a high intensity Cd light source provided by an electrodeless discharge tube, excited in a thermostatted microwave cavity. The analytical sensitivity of the technique is sufficient to permit dilution (1 in 5) of blood, before aspiration into the air-hydrogen flame. The method is rapid ( 25 duplicates/hour), and gives acceptable precision (coefficient of variation within batch $2.5 \%$, between batch $8.1 \%$ ). The method was applied to a reference population and to three different groups of industrial workers. The reference population had a mean blood concentration of $35.1 \mathrm{nmol} \mathrm{Cd}$ /litre. Group 1 (general categories of worker) had $65.2 \mathrm{nmol} \mathrm{Cd} / 1$, Group 2 (demolition workers), $137.9 \mathrm{nmol} \mathrm{Cd} / 1$, and Group 3 (shipbreakers), 105.9 $\mathrm{nmol} \mathrm{Cd/l}$. There was a relationship between increases in blood $\mathrm{Cd}$ and in blood $\mathrm{Pb}$ which was statistically significant for Group 3.

The health hazards of increased cadmium absorption from industrial and environmental pollution are well recognised (Friberg et al., 1971). Absorbed Cd enters the circulating blood and is then deposited in various tissues such as kidney and liver, where it is bound to protein. The metal is very slowly excreted and continued exposure results in a build up of tissue levels leading eventually to renal damage and other toxic effects.

Present screening procedures are based upon the detection of proteinuria and of an increased urinary excretion of Cd. It is known, however, that such tests will be positive only when sufficient $\mathrm{Cd}$ has been absorbed to cause some degree of renal impairment. Blood Cd concentration does not reflect the body burden of tissue-bound Cd (Harvey et al., 1975), but will, if increased, give an indication of recent absorption of the toxic metal. Routine blood $\mathrm{Cd}$ analysis could therefore allow the selection of individual workers for further clinical and biochemical examination (Lauwerys et al., 1974) and give an early indication that improvement in

Received for publication 24 February 1976

Accepted for publication 17 January 1977 ventilation, and other industrial hygiene measures, are required.

Until recently the routine measurement of blood Cd was difficult, due in part to the low concentration of the metal found in blood, and to technical problems of blood Cd assay by commonly available techniques. Various normal ranges have been reported for blood $\mathrm{Cd}$ in non-exposed subjects (Friberg et al., 1971), but it is now generally agreed that normally less than $45 \mathrm{mmol} \mathrm{Cd} / 1$ (5 $\mu \mathrm{g}$ $\mathrm{Cd} / \mathrm{l})$ will be found, although somewhat increased concentrations may be expected in the blood of cigarette smokers (Nandi et al., 1969).

Cernik and Sayers (1975) have recently described a practicable method based upon a carbon cup, atomic absorption procedure, which was applied to blood samples obtained from men in cadmium-using industry. We now report our investigations using an atomic fluorescence method, which has the advantages of the speed and simplicity of other flame photometric techniques, yet has adequate sensitivity. The procedure was used on blood samples supplied in a routine manner by Employment Medical Advisers, and taken from men in industry who were known to be at risk of increased lead absorption but who were not directly employed in cadmium-using processes. 


\section{Methods}

\section{APPARATUS}

The instrument used for all measurements was a Perkin-Elmer 290B atomic absorption spectrometer and this was coupled to a Honeywell Electronik 19 strip chart recorder.

The light source used to generate the atomic fluorescence was a $\mathrm{Cd}$ electrodeless discharge tube (EDT), manufactured by EMI Limited, and operated in a Broida 210L microwave cavity, powered by a Microtron Mark I microwave generator.

An air-hydrogen flame was used and the standard long slot burner was replaced by one specially manufactured. A stainless steel tube of $1^{\prime \prime}(25.4 \mathrm{~mm})$ outer diameter, $1 / 32^{\prime \prime}(0.71 \mathrm{~mm})$ wall thickness, which fitted into the normal burner slot, had a burner head of the same material welded to it. This burner head had two rows of nine holes (drill size no. 52).

As atomic fluorescence signals are similar to normal flame emission signals, the spectrometer was coupled to the flame emission accessory available from the manufacturer (part no. 290-0200).

The EDT light source was mounted in front of the spectrometer so that its light path was at right angles to the optical measurement path of the instrument. The emission chopper (mechanical type) was then mounted between the EDT and the air-hydrogen flame so that the light source was modulated at the same frequency and in phase with the amplifierdetector system of the spectrometer. Using this system, fluorescence signals generated in the flame by the intense light source could be measured without interference from thermal emissions from the flame. The light source and chopper were mounted on a single gantry which could be removed and replaced in a reproducible position when required. The EDT source was maintained at a constant temperature by passing nitrogen gas at an elevated temperature (about $300^{\circ} \mathrm{C}$ ) through the open end of the microwave cavity.

\section{ANALYTICAL PROCEDURE}

Reagents All reagents were of the highest purity available, and each batch was checked for $\mathrm{Cd}$ content. Water from a specially designed deionisation unit which contained five different resins was used for the preparation of all solutions. All glassware was acid-washed and rinsed in deionised water before use.

Cadmium standards Aqueous Cd standards were found to be suitable, thus obviating the addition of Cd to pooled blood required by other procedures (Cernik and Sayers, 1975). A stock Cd solution was made by dissolving $\mathrm{CdO}$ (analytical reagent grade) in hydrochloric acid. By dilution with hydrochloric acid $(0.01 \mathrm{~mol} / \mathrm{l})$ working standards in the range 10 to $100 \mathrm{nmol} \mathrm{Cd} / \mathrm{l}$ were prepared daily.

Blood samples Blood $(5 \mathrm{ml})$ was collected by venepuncture, using disposable syringes, needles and plastic sample tubes containing anticoagulant (potassium EDTA or lithium heparin). Negligible amounts of $\mathrm{Cd}$ were found during checks of contamination of the blood collecting procedure.

Stability of blood $C d$ Venous blood collected as described above was stored for more than a month either at 4 to $10^{\circ} \mathrm{C}$, or at -10 to $-20^{\circ} \mathrm{C}$. No significant change in $\mathrm{Cd}$ concentration was noted for blood containing about $45 \mathrm{nmol} \mathrm{Cd} / 1$ or $250 \mathrm{nmol}$ $\mathrm{Cd} / \mathrm{l}$. It was found best to store whole blood samples in the frozen state as the resultant haemolysis gave a more homogeneous solution.

Blood sample preparation Blood $(1 \mathrm{ml})$ was taken from the thawed samples after ensuring thorough mixing, added to a clean $10 \mathrm{ml}$ centrifuge tube, and diluted to $5 \mathrm{ml}$ with hydrochloric acid. Because $\mathrm{Cd}$ in blood is mainly bound to erythrocytes (Nordberg et al., 1971) the acid diluent contained $0.5 \% \mathrm{v} / \mathrm{v}$ Triton X, a detergent which ensures complete haemolysis. The diluted blood sample was then centrifuged ( $30 \mathrm{~s}, 3000 \mathrm{rev} / \mathrm{min})$ to remove cellular debris, and aspirated directly into the air-hydrogen flame.

Operation of the instrument The EDT source was operated at a microwave power of $25 \mathrm{~W}$, a nitrogen flow rate of $10 \mathrm{l} / \mathrm{min}$, and a temperature of $288^{\circ} \mathrm{C}$. The spectrometer was operated at a wavelength of $228.8 \mathrm{~nm}$ and a spectral band width of $2 \cdot 0 \mathrm{~nm}$. The air flow meter allowed a flow of $14.001 / \mathrm{min}$ at a feed pressure of $241.5 \mathrm{kPa}\left(35 \mathrm{lbf} / \mathrm{in}^{2}\right)$; the hydrogen flow meter allowed a flow of $14 \cdot 201 / \mathrm{min}$ at a feed pressure of $55 \cdot 2 \mathrm{kPa}\left(8 \mathrm{lbf} / \mathrm{in}^{2}\right)$.

Calibration All working standards (0, 10, 20, 40, $80,100 \mathrm{nmol} \mathrm{Cd} / \mathrm{l})$, were aspirated and followed by the diluted blood samples. Their cadmium content was determined from a calibration graph of recorder signal peak height versus $\mathrm{Cd}$ concentration. Blank solutions gave no significant readings.

Analytical performance The detection limit was less than $1 \mathrm{nmol} \mathrm{Cd} / \mathrm{l}$ and the useful working range 5 to $100 \mathrm{nmol} \mathrm{Cd} / \mathrm{l}$. The precision was $2.5 \%$ within batch, and $8.1 \%$ between batch. There was satisfactory recovery of $\mathrm{Cd}$ added to blood, and the method had an analytical rate of 25 duplicate analyses per hour. Blood lead Blood $\mathrm{Pb}$ was determined by the Delves microsampling technique, using an IL251 atomic absorption spectrophotometer with continuous background correction.

POPULATIONS STUDIED

Reference populations Blood $(1 \mathrm{ml})$ was taken from 
Table Blood cadmium concentration in a reference population and three groups of workers

\begin{tabular}{|c|c|c|c|c|}
\hline & Reference population & $\begin{array}{l}\text { All lead workers } \\
\text { Group } 1\end{array}$ & $\begin{array}{l}\text { Demolition workers } \\
\text { Group } 2\end{array}$ & $\begin{array}{l}\text { Shipbreakers } \\
\text { Group } 3\end{array}$ \\
\hline $\begin{array}{l}n \\
\text { Mean Cd concentration } \\
\text { S.D. } \\
\text { Range }\end{array}$ & $\begin{array}{l}105 \\
35 \cdot 1(3.95) \\
10 \cdot 5(1 \cdot 11) \\
17 \cdot 0-62 \cdot 0 \quad(2 \cdot 0-7 \cdot 0)\end{array}$ & $\begin{array}{l}100 \\
652(7 \cdot 33) \\
35 \cdot 8(4 \cdot 02) \\
16 \cdot 0-231 \cdot 0 \quad(2 \cdot 8-26 \cdot 0)\end{array}$ & $\begin{array}{l}44 \\
137 \cdot 9(15 \cdot 51) \\
45 \cdot 0(5 \cdot 06) \\
62 \cdot 0-222 \cdot 0 \quad(7 \cdot 0-25 \cdot 0)\end{array}$ & $\begin{array}{l}39 \\
105.9(11.9) \\
29.7(3.34) \\
31.0-178.0 \quad(3.5-20.0)\end{array}$ \\
\hline
\end{tabular}

Concentrations shown as $\mathrm{nmol} \mathrm{Cd} / \mathrm{l}$ and ( $\mu \mathrm{g} \mathrm{Cd} / \mathrm{l})$.

samples (lithium heparin tubes) submitted to the hospital laboratory for routine analysis. This blood, surplus to requirement, was stored frozen until required. These samples served as a reference population of persons known not to be industrially exposed to $\mathrm{Cd}$ at the time of blood collection.

Industrial workers Blood $(1 \mathrm{ml})$ was taken from samples submitted for routine analysis of blood $\mathrm{Pb}$ as part of health checks by Employment Medical Advisors. Group 1 comprised 100 men drawn from all categories of industrial worker known to be at risk of increased $\mathrm{Pb}$ exposure. The 44 subjects in Group 2 were demolition workers engaged in metal cutting operations, and the third group studied comprised 39 men engaged in shipbreaking industry. The values obtained for these populations are shown in the table.

\section{Discussion}

The average level of blood $\mathrm{Cd}$ in the reference population, $35 \cdot 1 \mathrm{nmol} \mathrm{Cd} / \mathrm{l}$, is similar to the control value, $35.6 \mathrm{nmol} \mathrm{Cd} / \mathrm{l}$, reported by Cernik and Sayers (1975) and to other published values for nonexposed subjects (Friberg et al., 1971). The blood lead concentrations for the reference population are plotted against blood $\mathrm{Cd}$ concentration as shown in Figure 1, which indicates the approximate upper limits of normal.

All the industrial groups investigated showed increased levels of blood Cd, the greatest increases occurring in Groups 2 and 3. However these changes are moderate when compared with those values reported for men in Cd-using industry. For example, in pigment workers exposed to Cd dust, Cernik and Sayers (1975) found a mean value of $237 \mathrm{nmol} \mathrm{Cd/l}$, and men in the smelting industry had mean blood $\mathrm{Cd}$ levels of $463 \mathrm{nmol} \mathrm{Cd} / \mathrm{l}$ after exposure to Cd fumes.

It must be emphasised again that the increases in blood Cd do not reflect the extent of tissue accumulation of Cd, which can be directly measured by an in vivo neutron activation technique (Harvey et al., 1975). Even moderate increases in blood Cd, however, provide evidence of recent absorption and, if

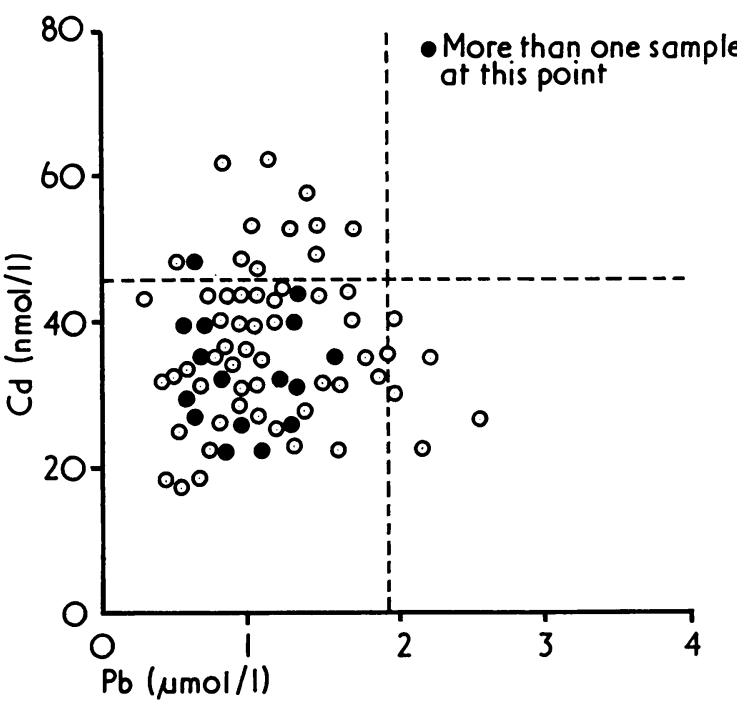

Fig. 1 Reference population, relationship between blood $\mathrm{Pb}(\mu \mathrm{mol} / \mathrm{l})$ and blood $\mathrm{Cd}(\mathrm{nmol} / \mathrm{l})$. Approximate upper limits of normal indicated by dashed lines.

this is part of a continuous exposure period, considerable $\mathrm{Cd}$ tissue deposition could well occur.

Throughout the study we noted a tendency for men with raised blood $\mathrm{Pb}$ levels to have increased blood Cd concentrations. This was most obvious in Groups 2 and 3. In the shipbreakers (Group 3) the relationship was particularly striking (Figure 2) and was statistically significant $(r=0.9)$. Ingestion of metal fumes produced during metal cutting may be the common source of both metals, as $\mathrm{Pb}$ and $\mathrm{Cd}$ are commonly used in anticorrosion metal finishes.

The adverse health effects associated with chronic Cd exposure include hypertension and renal impairment, so that health statistics being collected for lead workers could be influenced by such unsuspected $\mathrm{Cd}$ absorption. In addition, it should be borne in mind that the oral chelating agent penicillamine, used to treat severe lead intoxication, may well be contra- 


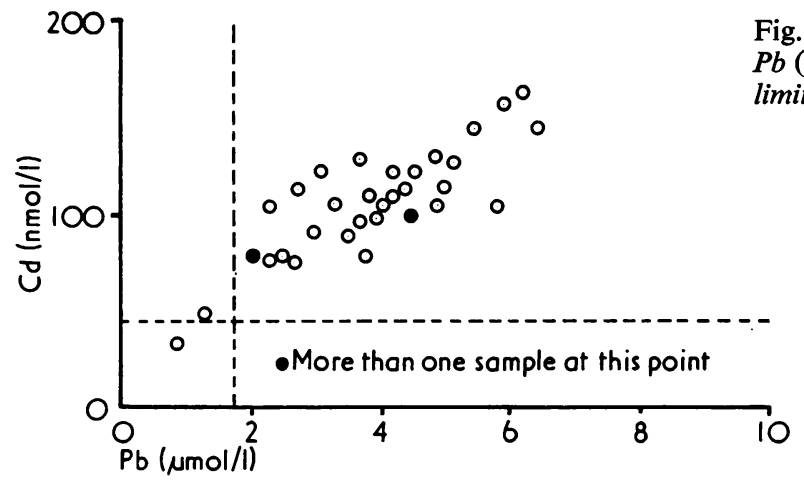

Fig. 2 Group 3, shipbreakers. Relationship between blood $\mathrm{Pb}(\mu \mathrm{mol} / \mathrm{l})$ and blood $\mathrm{Cd}(\mathrm{nmol} / \mathrm{l})$. Approximate upper limit of normal indicated by dashed lines. $(\mathrm{r}=0.9)$.

indicated in cases where $\mathrm{Cd}$ absorption can be proved (Lyle et al., 1968).

Although the long-term health effects of chronic exposure to $\mathrm{Cd}$ are not yet clear, (Buell, 1975), future epidemiological studies should include blood $\mathrm{Cd}$ analysis. This will help to define the extent of industrial and environmental exposure to this potentially dangerous metal.

The Authors thank Dr Eric Blackadder and EMAS Staff for provision of blood samples and permission to publish the results.

\section{References}

Buell, G. (1975). Some biochemical aspects of cadmium toxicology. Journal of Occupational Medicine, 17, 189-195.

Cernik, A. A., and Sayers, M. H. P. (1975). Application of blood cadmium determination to industry using a punched disc technique. British Journal of Industrial Medicine, 32, 155-162.
Friberg, L., Piscator, M., and Nordberg, G. F. (1971). Cadmium in the Environment. C.R.C. Press: Cleveland, Ohio, USA.

Harvey, T. C., Mclennan, J. S., Thomas, B. J., and Fremlin, J. H. (1975). Measurement of liver-cadmium concentrations in patients and industrial workers by neutron-activation analysis. Lancet, 2, 1269-1272.

Lauwerys, R., Buchet, J.-P., Roels, H. A., Brouwers, J., and Stanescu, D. (1974). Epidemiological survey of workers exposed to cadmium. Archives of Environmental Health, 28, 145-148.

Lyle, W. H., Green, J. N., Gore, V., and Vidler, J. (1968). Enhancement of cadmium nephrotoxicity by penicillamine in the rat. Postgraduate Medical Journal, (Supplement), 44 18-21.

Nandi, M., Jick, H., Slone, D., Shapiro, S., and Lewis, G. P. (1969). Cadmium content of cigarettes. Lancet, 2, 1329 1330.

Nordberg, G. F., Piscator, M., and Nordberg, M. (1971). On the distribution of cadmium in blood. Acta Pharmacologica et Toxicologia, 30, 289-295.

Syversen, T. L. M. (1975). Cadmium-binding in human liver and kidney. Archives of Environmental Health, 30, 158-161. 